\title{
The Fight against Administrative Improbity for the Guarantee of the Human Right to Water
}

\author{
Ana Julia Ramos Padua \\ School of Law, Bauru University Center \\ Campus 5 - Praça 9 de Julho, Bauru, Brazil \\ Luiz Nunes Pegoraro \\ School of Law, Bauru University Center \\ Campus 5 - Praça 9 de Julho, Bauru, Brazil
}

\begin{abstract}
The article aims to present the connection between acts of administrative improbity and the current difficulty for the universalization of water and basic sanitation, which is one of the 17 objectives of Agenda 2030 for Sustainable Development. First, an analysis is made of the Human Rights approach in the Brazilian legal system, moving on to an explanation of how these are applied in the reality of the country. And through the documental analytical methodology, it shows the importance of the right to water and sanitation, besides addressing the problems faced by these rights. Finally, the concept of administrative improbity is presented, discussing the definition, modalities and ways of fighting it, and in this last point, the importance of implementing the right to water and sanitation, as well as other human rights.
\end{abstract}

Keywords: Administrative Improbity; Corruption; Public Policies; Human Rights; Right to Water;

DOI: $10.7176 /$ RHSS/11-12-03

Publication date:June $30^{\text {th }} 2021$

\section{Introduction}

This article deals with a current and important issue, which is being much discussed in view of the concerns that exist around it, since it is essential to life and many people still do not have this right: the human right to water and basic sanitation.

Therefore, it first approaches some points on the issue of Human Rights in Brazil, presenting how they are arranged in the legal system, and then presenting public policies as an instrument to implement these fundamental rights.

After a brief introduction on how human rights are approached in Brazil, we move on to a more restrictive analysis on the right to water and sanitation, presenting the barriers that prevent the universalization of this right. The most used explanations for the issue of precarious access to water and sanitation in some states are usually linked to geographic or economic problems in a determined region. However, there is a bigger problem: administrative improbity. And it is on this premise that the proposal of this work is based.

\section{Human Rights in Brazil}

Human Rights are natural and universal rights, meaning that they are inherent to all human beings, without any conditions, and they desire to guarantee and provide human dignity. Throughout history, these rights have been guaranteed in some internal regulations of certain states, such as the Magna Carta (1215) of England, the Bill of Rights (1689) of the United States, and the Declaration of the Rights of Man and of the Citizen (1789) of France. But it was only after the Second World War that the whole concept of human rights in an equality and universal way, with the ideal that everyone deserved a dignified life, was consolidated and posited in an international document, signed by several nations, thus giving rise to the 1948 Universal Declaration of Human Rights, adopted and proclaimed by the General Assembly of the United Nations, which generated influence in the constitutions promulgated later.

In Brazil, Human Rights were only affirmed in the Federal Constitution of 1988, since previously the country lived moments marked by the disrespect of these rights, as during the period of slavery and the Military Regime.

The 1988 Federal Constitution is also known as the "citizen" Constitution, and takes this name because it attributed rights to all people, and positioned citizens at the center of government actions, in addition to being based on the Principle of the Dignity of the Human Person. When these rights are affirmed in the Brazilian legal system, they are called "fundamental rights". As Ingo Sarlet (2009 : 396) teaches, "in every fundamental right there is present a content or, at least, some projection of the dignity of the person". In this way, the importance of fundamental rights for individuals and for the democratic rule of law is realized. In the doctrine, these rights are divided into dimensions. The first-dimensional fundamental rights are based on the ideology of liberalism 
(rationalist jusnaturalism), and in this way aim at freedoms such as freedom of movement, religious freedom, freedom of expression, among others, being these civil and political rights. The second dimension fundamental rights are based on equality, and had socialism (Marxism) as a basis, thus encompassing economic, social and cultural rights. Finally, there are the third dimension fundamental rights, which are based on fraternity, covering all diffuse rights, such as the right to the environment, the right to peace, development, the right to water and sanitation, etc. In view of this, Brazil has a complete legal order regarding the guarantee of human rights.

In order for human rights to be transmitted from theory and applied in practice, public policies are necessary, which means, the realization of governmental programs, actions and decisions that aim at satisfying the needs of the population, the public interest, and ensuring fundamental rights, aiming at providing a dignified life to citizens. Above all, it is not enough to simply carry out public policies; they must also be effective and of quality. On the subject, Eduardo Appio (2005 : 143-144) affirms that: "Public policies can be conceptualized as instruments for implementing political programs based on state intervention in society with the aim of ensuring equal opportunities for citizens, with the scope of ensuring the material conditions for a dignified existence for all citizens." In this way, the importance of carrying out public policies for the realization and guarantee of fundamental rights becomes evident.

Regardless of the dimension, it is the duty of the State to guarantee the realization of fundamental rights through public policies. However, it is failing with its obligations, leaving citizens helpless and far from a dignified life, being easy to perceive the problems faced in the field of health, education, increase of social inequalities, among others. It is not enough to have a complete legal system regarding Human Rights, it is necessary to have public policies to make these rights effective.

Facing the precariousness in guaranteeing some Human Rights around the world, the UN created the 2030 Agenda, which is an action plan that seeks to achieve by 2030 the 17 Objectives of Sustainable Development and the 169 goals present in the document, to guarantee everyone a dignified life. Among the goals are the reduction of social inequalities, eradication of poverty and hunger, quality education, health and welfare and the universalization of water and basic sanitation, being this the central theme of this work.

\subsection{The right to water and sanitation}

Water is an indispensable element for human survival, but it was not expressly described in legal systems as a human right, it was only seen implicitly in international documents. However, in 2010, through Resolution 64/292 of the General Assembly of the United Nations, the right to water and basic sanitation was posited as a human right. In the Brazilian legal system, this right is not described among the fundamental rights in the 1988 Federal Constitution, but the doctrine considers it implicit in other rights, since it is not possible to have health, education, and much less life, without quality water, since this is a basic human need and the basis for guaranteeing human dignity.

As has been said before, many states are not guaranteeing human rights to their citizens, and this is no different regarding the right to water and sanitation. According to the United Nations International Children's Emergency Fund (UNICEF), more than 2 billion people do not have water in the necessary quality and quantity, and 844 million do not have any drinking water service. These figures are even more frightening when it comes to basic sanitation, as more than 4 billion people do not have safely managed sanitation, and 2 billion do not even have basic sanitation.

The precarious access to water and sanitation generates several consequences, the most apparent being on health, since countless diseases come from this situation, such as intestinal worms, leptospirosis, schistosomiasis, cholera and diarrhea, resulting in approximately 3.5 million deaths per year. These are only some of the problems caused, since they extend to other areas, for as human rights have an interdependent relationship, the problem generated to one right is spread to others. It is like a current: without water and sanitation there is no health, without health there is no education, work, leisure and no life.

Insufficient economic resources, lack of water in some regions and pollution are cited as the main causes of lack of access to drinking water and sanitation. However, these problems could be faced by the Public Government, but this does not occur due to the recurrence of acts of administrative improbity and corruption.

It is expected that with the objective of the universalization of water and sanitation present in Agenda 2030 there will be an improvement in the data presented previously. However, UNICEF estimates that 90 countries are not likely to achieve this goal, as they are making very slow progress. Brazil is supposed to be included in this hypothesis, because according to data from the National Confederation of Industry (CNI), if Brazil continues with the average investments made today, the country will only achieve universalization in 2060, 30 years after Agenda 2030, which is very worrying.

Given the low expectation of progress in Brazil, the Federal Government created Law 14.026/2020, known as the new Legal Framework for Basic Sanitation, with the goal of achieving universalization by the year 2033, by offering incentives for investment in the area. However, this is not enough, for the objective to be reached it is necessary to have an intense fight against administrative improbity, since not all investment is directed to the 
accomplishment of quality public policies.

\section{Administrative Improbity}

In Brazil it is common to see news about acts of corruption and administrative improbity. In many moments these terms are approached as synonyms, but there is a difference between them. Both acts are performed by public agents, and can be exteriorized by actions or omissions, which seek undue advantages for their own benefit or for another private individual. The difference is that corruption is a criminal type and has as its focus the deviation from the public function and illicit enrichment, but the improbity is not limited to this. Administrative improbity has civil prevision and is more extensive than an act of corruption.

Administrative improbity can be defined as an illicit act, performed by a public agent who, instead of seeking to satisfy public interests, that is, to exercise the public function, ends up aiming only at his private interests.

According to Law 8.429/92 (Administrative Improbity Law), there are three kinds of improper acts: the acts that matter in illicit enrichment (art. 9), the acts that generate damage to the treasury (art. 10), and finally, the acts that attack the principles of public administration (art. 11). All these acts cause damages to the treasury, including about the water and sanitation system.

These acts occur both in the issue of detour of funds, in the case of funds that should be destined to public policies, as well as by the constant omission of public authorities in face of the population's needs.

It is possible to prove that improbity is the major impediment to the universalization of water and sanitation, by analyzing the regions of Brazil. The most arid region is the Northeast, while the region with the most water resources is the North, but the question is reversed when it comes to access to drinking water, no matter how arid the Northeast is, its population has more access to water than the population of the North. Therefore, the problem is not the insufficiency of water resources, but the acts of administrative improbity, be it by the deviation of funds, frauds in bidding or by the omission of the Public Authorities, in any case these acts prevent the development of public policies.

Without acts of administrative improbity, it would be possible to carry out quality works for the transposition and depollution of rivers, constructing artesian wells to capture water from aquifers, in the same way as investing in sewage treatment stations.

In this way, the fight against administrative improbity, which can occur through the Court of Contests of the Union (TCU), by more rigid laws created by the Legislative Branch, by the intervention of the Judiciary, when provoked, in public policies, and especially by the vote of the population, who must be aware of the harmful effects of administrative improbity, to choose a representative who does not commit these acts, and who aims only to satisfy public interests, is of utmost importance.

\section{Conclusion}

Through an analysis of the Brazilian legal system, it is possible to perceive the presence of countless fundamental rights, but when visualizing the reality lived by Brazilians, it is possible to see that the rights cited in the system are not being effective, applied on a material level, which leaves many citizens far from a dignified life.

One of the most important rights for human survival, the right to water and sanitation, faces several obstacles to achieve universalization, such as pollution, geographical distribution of water and insufficient economic resources. However, through this research it was possible to conclude that there is a bigger problem, the administrative improbity. In this way, it presents the importance of fighting administrative improbity for the realization of the right to water and basic sanitation, as well as for all other fundamental rights, so that everyone can have a dignified life.

\section{References}

Appio, Eduardo. (2005). A ação civil pública no Estado Democrático de Direito. Juruá Editora.

Araujo, Luiz Alberto David; Nunes, Vidal Serrano. (2005). Curso de direito constitucional. Saraiva.

Conselho empresarial brasileiro para o desenvolvimento sustentável. (19 mar 2014). Brasil ocupa a $112^{a}$ posição no ranking de saneamento. Sustentável blog. https://cebds.org/estudo-destaca-beneficios-com-expansaosaneamento-brasil/

Dallari, Dalmo de Abreu. (2004). Direitos humanos e cidadania. Moderna.

Fundo das nações unidas para a infância. (13 de julho de 2017). 2,1 bilhões de pessoas não têm acesso a água potável em casa, e mais do dobro de pessoas não tem acesso a saneamento seguro. https://www.unicef.org/angola/comunicados-de-imprensa/21-bilh\%C3\%B5es-de-pessoas-n\%C3\%A3o$\mathrm{t} \% \mathrm{C} 3 \%$ AAm-acesso- $\% \mathrm{C} 3 \% \mathrm{~A} 1$ gua-pot $\% \mathrm{C} 3 \% \mathrm{~A} 1$ vel-em-casa-e-mais-do-dobro

Fachin, Zulmar; Marcelino da Silva, Deise. (2012). Acesso à Água Potável Direito Fundamental de Sexta Dimensão. Millennium. 
Fazzio Junior, Waldo. (2016). Improbidade Administrativa. Atlas.

Ministério Público Federal. (2020). Mapa da Improbidade. Transparência Ministério Público. https://aplicativos.mpf.mp.br/mapas/mpf/improbidade/

Mota, Camilla Veras. (2019). Por que quase metade do Brasil não tem acesso a rede de esgoto. BBC News Brasil. https://www.bbc.com/portuguese/brasil-49399768

Saiani, Carlos C. S; Júnior, Rudinei T. (2010). Evolução do acesso a serviços de saneamento básico no Brasil (1970 a 2004). Revista Economia e https://www.scielo.br/pdf/ecos/v19n1/a04v19n1.pdf.

Sarlet, Ingo Wolfgang. (2009). A eficácia dos direitos fundamentais: uma teoria geral dos direitos fundamentais na perspectiva constitucional. Livraria do Advogado.

Transparency International. Corruption https://www.transparency.org/en/cpi/2019/results/bra

Instituto Trata (2018). https://www.painelsaneamento.org.br/localidade/compare?id=1

Perceptions Index. ira, Andréia Costa. (2016). O direito humano á água. Arraes Editores. 